\title{
Effect of Brood Stock Size Combination on Reproductive Performance of Nile Tilapia (Oreochromis niloticus)
}

\author{
Said, M.M. ${ }^{1}$ and A. S. H. Elsherbeny ${ }^{2 *}$ \\ ${ }^{1}$ Aquaculture Department, Faculty of Fish Resources, Suez University, Suez, Egypt \\ ${ }^{2}$ Fish Population Dynamics Dept., Fisheries Division, National Institute of Oceanography and Fisheries, Suez, Egypt
}

Received: $1 / 9 / 2015$

\begin{abstract}
Two hundred and four Oreochromis niloticus brood stock were used in the experiment. Males and females were classified into three groups according to their body weights as follows; large $(400-650 \mathrm{~g})$, medium $(160-300 \mathrm{~g})$ and small (80-120 g) which coded A, B and C; respectively. All possible nine combinations between the three weight categories were conducted. Testes and ovary weights were significantly affected $(\mathrm{P}<0.001 \& \mathrm{P}<0.01$ respectively) with different broodstock size groups. The highest testes and ovary weights were recorded at large-sized group, while it decreased steadily from medium to small-sized groups; respectively. Absolute fecundity, relative fecundity, and egg weight were all significantly affected $(\mathrm{P}<0.01)$ with female size. The highest absolute fecundity and egg weight were obtained in large-sized females while the highest relative fecundity was obtained in the small-sized females. Gonado-somatic index didn't affect significantly with the various sizes of the female. Total collected fry number and growth performance represented as fry weight, length, and condition factor at the age of 6 weeks were all significantly $(\mathrm{P}<0.001)$ affected with broodstock size combinations. The highest fry numbers were obtained from the $\mathrm{AB}, \mathrm{AC}$, and $\mathrm{BC}$ combinations respectively, whilst the lowest were recorded by $\mathrm{BA}$ and $\mathrm{CB}$ combinations. The highest fry weight and length at the age of 6 weeks after hatching were obtained from combinations AA, BB, and CA respectively. Nonetheless, the AC combination showed the lowest body weight and length. The highest condition factor was recorded by $\mathrm{AB}$ combination while the lowest was for the AC's.
\end{abstract}

Keywords: Nile tilapia, Broodstock, Size combination, Reproduction, Fecundity, Egg weight, Fry performance.

\section{INTRODUCTION}

Tilapia has been developed globally to be the second most important cultured freshwater fish. Tilapia Currently, is farmed commercially in almost 100 countries worldwide (FAO, 2011). There is a growing consensus that tilapias can become the world's most important warm water cultured fish in tropical and subtropical countries (Fitzsimmons, 2010). Global tilapia production is expected to almost double from 4.3 million tons per year in 2010 to 7.3 million tons a year in 2030. With these estimates, tilapia will likely be one of the main contributors to the fastest growth in global aquaculture aside from carp and catfish (FAO, 2014).

The main advantages of tilapia are its general hardiness, ease of breeding, rapid growth rate, low cost of production, easily spawning in captivity, tolerable to poor water quality, ability to efficiently convert organic and domestic wastes into high quality protein, flesh quality, and good taste (El-Saidy and Gaber, 2005 and Borgeson et al., 2006).

The reproductive performance of Nile tilapia includes many aspects like absolute fecundity, relative fecundity, gonads weight, egg weight, gonado-somatic index (GSI), and fry performance (Bhujel, 2000; Gómez-Márquez et al., 2003; Mohammed et al., 2014). As there are wide variations in the reproductive performance among species and individuals within the species (Kirpichnikov, 1981; Macaranas et al., 1997), many studies had been conducted to investigate different factors involved in tilapia reproductive performance. Some studies reported different relationships between female weight and absolute fecundity (Shalloof and Salama, 2008), relative fecundity (Farag, 2003), ovary weight and Gonado somatic index (Mohammed et al., 2014) and egg weight (Fath El-Bab et al., 2011).
Furthermore, other studies reported a mentioned some effects of female size on fry production performance of Tilapia (Bhujel, 2000; El-Saidy and Gaber, 2005; Mohammed et al., 2014).

The study aimed to investigate the effects of the size combination of the breeding stock on different reproductive performance aspects of Nile tilapia in order to determine the optimum breeding stock management methods that may improve hatcheries production on the commercial scale.

\section{MATRIALES and METHODS}

\section{Fish management and experimental design:}

The experiment was conducted from $1^{\text {st }}$ of May until the $20^{\text {th }}$ of July 2015 at a commercial tilapia hatchery that located at San El-Hagar about $60 \mathrm{~km}$ northeast of Ismalia, Egypt. Two hundred and four (138 females and 66 males) $O$. niloticus broodstock were used in the experiment. The brood fish were maintained, where each sex was separated for a 25-day period in $12 \mathrm{~m}^{2}$ hapas installed in a 0.25 ha pond with a stocking density 4 fishes $/ \mathrm{m}^{2}$. After such preparing period males and females were classified into three groups according to their body weights to large $(400-650 \mathrm{~g})$, medium $(160-300 \mathrm{~g})$, small $(80-120 \mathrm{~g})$ and named A, B, and C; respectively (Table 1). All possible mating combinations between the three weights categories were conducted through nine mating groups, each consisting of 2 males and 6 females, all with two replicates. Mating was carried out in $2 \mathrm{~m}^{2}$ hapas installed in a 0.2 ha pond. After 14 days, swim-up fry were collected separately from each hapa and then all females were checked and any eggs or fry still incubated inside the mother's mouth were also collected and counted. Fry from each mating type were stocked in two different $2 \mathrm{~m}^{2}$ hapas at a stocking density 200 
fry $/ \mathrm{m}^{2}$ for further 6 weeks rearing period. Brood fish were fed $30 \%$ crude protein at the rate of $3 \%$ of their total body weight twice a day while Fry were fed ad libitum four times a day with a commercial diet containing $40 \%$ crude protein. All farm ponds filled with filtered canal water from Al-Salam canal. Water temperature ranged between 24 and $28^{\circ} \mathrm{C}, \mathrm{pH}$ value ranged between 7.2-7.4 representing the alkaline medium needed for tilapia fish, and water salinity ranged between $2520-2700 \mathrm{mg} / \mathrm{L}$.

Table (1): Brood-stock mating combinations in the order $(\hat{\mathrm{O}} \mathrm{X}+)_{\text {. }}$

\begin{tabular}{|c|c|c|c|}
\hline $\begin{array}{l}\text { Code } \\
\text { Weight }\end{array}$ & $\begin{array}{c}A\left({ }^{\lambda}\right) \\
(400-650 \text { g. })\end{array}$ & $\begin{array}{c}\text { B }\left({ }^{\Uparrow}\right) \\
(160-300 \text { g. })\end{array}$ & $\begin{array}{c}C\left({ }^{\Uparrow}\right) \\
\text { (80-120 g.) }\end{array}$ \\
\hline $\mathbf{A}(+)$ & AA & $\mathrm{AB}$ & $\mathrm{AC}$ \\
\hline $\mathbf{B}(+)$ & BA & BB & $\mathrm{BC}$ \\
\hline $\mathbf{C}(q)$ & CA & CB & $\mathrm{CC}$ \\
\hline
\end{tabular}

\section{Studied traits}

A total of 60 brood-stock were used to investigate total body weight $(\mathrm{g})$, total length $(\mathrm{cm})$, ovary weight $(\mathrm{g})$, testes weight $(\mathrm{g})$, absolute fecundity, relative fecundity, egg weight (mg), and Gonado-somatic index. Absolute fecundity (AF) was determined according to Hunter et al. (1992) as follow: $\mathrm{F}=(\mathrm{W} / \mathrm{w}) * \mathrm{X}$; where $\mathrm{F}$ is the absolute fecundity, $\mathrm{W}$ : the weight of gonad, $\mathrm{w}$ : the mean weight of sub-samples and X: the counted number of mature eggs in the sub-sample. Relative fecundity (RF) was determined as the total number of eggs per unit weight of fish (Hunter et al., 1992), while gonadosomatic index was calculated according to the formula: GSI $=$ [weight of ovary $(\mathrm{g}) /$ female body weight $(\mathrm{g})]$ * 100 (de Vlaming et al., 1982).

In order to compare the fry production performance between all possible combinations, the total collected fry numbers from each hapa was recorded. At 6 weeks old after hatching, thirty fry from each hapa were individually weighed $(\mathrm{g})$ and their total length were measured $(\mathrm{cm})$ and used to calculate the condition factor. Furthermore, survival rate was calculated for each hapa. Survival rate (\%) was calculated as $=$ Number of fish at the end of the experiment/number of fish at the start of the experiment*100, while condition factor was calculated according to the formula:

$\mathrm{K}=\left(\right.$ Weight $(\mathrm{g}) /$ Length $\left.(\mathrm{cm})^{3}\right) * 100($ Le Cren, 1951).

\section{Statistical analysis}

The data of brood-stock parameters were statistically analyzed using SPSS (2013) according to the following model: Yijk $=\mu+\mathrm{S}_{\mathrm{i}}+\mathrm{e}_{\mathrm{ij}}$, where, $\mu$ is the overall mean, $S_{i}$ is the fixed effect of female or male size $(i=1 \ldots 3)$, and eij is random error. The data of fry performance were statistically analyzed using SPSS (2013) program according to the following model: Yij = $\mu+C_{i}+h(c)_{i j}+e_{i j k}$, where, $\mu$ is the overall mean, $C_{i}$ is the fixed effect of $i_{\text {th }}$ the size brood-stock combination ( $i$ $=1 \ldots 9), h(c)_{i j}$ is the random experimental error of the $j^{\text {th }}$ hapa within the $i^{\text {th }}$ combination $(j=1,2)$ and $e_{i j k}$ is the random sampling error. Means were tested for significant differences using Bonferoni test (Bonferroni, 1936).

\section{RESULTS AND DISCUSSION}

\section{Brood stock characterization}

The results showed that males body weight, length, and girth was significantly $(\mathrm{P}<0.001)$ affected with the different size groups. The highest male body weight, length, and girth were recorded in large-sized group while decreased for medium and small-sized respectively. Furthermore, the testes weight was also significantly $(\mathrm{P}<0.001)$ affected with the different size groups. The large-sized group has superior testes weight while it was decreased for medium and small-sized groups respectively (Table 2).

Table (2): Least squares means for some characteristics of $O$. niloticus males classified into three different weights.

\begin{tabular}{lcccc}
\hline & Body weight $(\mathbf{g})$ & Body length $(\mathbf{c m})$ & Body girth $(\mathbf{c m})$ & Testes weight $(\mathrm{g})$ \\
\hline Large (A) & $404^{\mathrm{a}} \pm 11.9$ & $28.01^{\mathrm{a}} \pm 0.5$ & $20.8^{\mathrm{a}} \pm 0.9$ & $2.89^{\mathrm{a}} \pm 0.29$ \\
Medium (B) & $195^{\mathrm{b}} \pm 11.9$ & $22.6^{\mathrm{b}} \pm 0.5$ & $16.1^{\mathrm{b}} \pm 0.9$ & $1.64^{\mathrm{b}} \pm 0.29$ \\
Small (C) & $95^{\mathrm{c}} \pm 11.9$ & $18.1^{\mathrm{c}} \pm 0.5$ & $14.2^{\mathrm{b}} \pm 0.9$ & $1.01^{\mathrm{b}} \pm 0.29$ \\
Significance & $* * *$ & $* * *$ & $* * *$ & $* * *$ \\
\hline
\end{tabular}

Means followed by different letter on the same column are different. *** Significantly different at $(\mathrm{P}<0.001)$.

The results showed that females body weight, length, and girths were all significantly $(\mathrm{P}<0.001)$ affected with size groups. The females body weight, length, and girths were highest at the large-sized group while decreased for medium- and small-sized respectively. The ovary and egg weights were significantly $(\mathrm{P}<0.01)$ affected with female weight. The highest ovary and egg weights were recorded at large-sized females while it was decreased for medium and small-sized respectively (Table 3 ). The results showed that absolute and relative fecundity were significantly $(\mathrm{P}<0.01)$ affected with female size. The highest of absolute fecundity was obtained at largesized group while, there values were lowered for medium and small-sized respectively. On the other hand, the highest of relative fecundity was obtained in smallest females size while, there values were lowered for medium and large-sized group respectively. The results showed that the gonado-somatic index didn't affect significantly according to different female weights. 
Table (3): Least squares means for some characteristics of $O$. niloticus females classified into three different sizes.

\begin{tabular}{|c|c|c|c|c|c|c|c|c|}
\hline & $\begin{array}{c}\text { Body } \\
\text { weight } \\
\text { (g) }\end{array}$ & $\begin{array}{c}\text { Body } \\
\text { length } \\
\text { (cm) }\end{array}$ & $\begin{array}{l}\text { Body } \\
\text { girth } \\
(\mathbf{c m})\end{array}$ & $\begin{array}{c}\text { ovary } \\
\text { weight } \\
\text { (g) }\end{array}$ & $\begin{array}{c}\text { Egg } \\
\text { weight } \\
\text { (mg) }\end{array}$ & $\begin{array}{c}\text { Absolute } \\
\text { fecundity } \\
\text { Egg }\end{array}$ & $\begin{array}{c}\text { Relative } \\
\text { fecundity } \\
\text { Egg / g }\end{array}$ & GSI \\
\hline Large (A) & $\begin{array}{l}528.3^{\mathrm{a}} \\
\pm 18.2\end{array}$ & $\begin{array}{l}30.6^{\mathrm{a}} \\
\pm 0.44\end{array}$ & $\begin{array}{l}22.6^{\mathrm{a}} \\
\pm 0.61\end{array}$ & $\begin{array}{l}16.7^{\mathrm{a}} \\
\pm 1.6\end{array}$ & $\begin{array}{l}7.17 .^{\mathrm{a}} \\
\pm 0.72\end{array}$ & $\begin{array}{l}2058.8^{\mathrm{a}} \\
\pm 263.9\end{array}$ & $\begin{array}{l}3.91^{\mathrm{b}} \\
\pm 1.02\end{array}$ & $\begin{array}{l}3.17 \\
\pm 0.6\end{array}$ \\
\hline Medium (B) & $\begin{array}{c}206^{\mathrm{b}} \\
\pm 18.2\end{array}$ & $\begin{array}{l}23.26^{\mathrm{b}} \\
\pm 0.44\end{array}$ & $\begin{array}{l}16.2^{\mathrm{b}} \\
\pm 0.61\end{array}$ & $\begin{array}{l}7.7^{\mathrm{b}} \\
\pm 1.6\end{array}$ & $\begin{array}{l}5.17^{\mathrm{ab}} \\
\pm 0.72\end{array}$ & $\begin{array}{l}1059.3^{b} \\
\pm 263.9\end{array}$ & $\begin{array}{l}5.28^{\mathrm{ab}} \\
\pm 1.02\end{array}$ & $\begin{array}{l}3.57 \\
\pm 0.6\end{array}$ \\
\hline Small (c) & $\begin{array}{c}97^{\mathrm{c}} \\
\pm 18.2\end{array}$ & $\begin{array}{l}18.3^{\mathrm{c}} \\
\pm 0.44\end{array}$ & $\begin{array}{l}12.4^{\mathrm{c}} \\
\pm 0.61\end{array}$ & $\begin{array}{l}3.05^{\mathrm{b}} \\
\pm 1.6\end{array}$ & $\begin{array}{l}3.76^{\mathrm{b}} \\
\pm 0.72\end{array}$ & $\begin{array}{c}711.3^{b} \\
\pm 263.9\end{array}$ & $\begin{array}{c}7.29^{\mathrm{a}} \\
\pm 1.02\end{array}$ & $\begin{array}{l}3.08 \\
\pm 0.6\end{array}$ \\
\hline Significance & $* * *$ & $* * *$ & $* * *$ & $* *$ & $* *$ & $* *$ & $* *$ & $\mathrm{~ns}$ \\
\hline
\end{tabular}

Means followed by different letters on the same column are significantly different. ${ }^{* *}$ Significant differences at $\mathrm{P}<0.01 .{ }^{* * *}$ Significant differences at $\mathrm{P}<0.001$. ns no significant differences.

Regarding to ovary and testes weights which were significantly affected with brood-stock body weight the results of the present study was in agreement with (Oso et al., 2013) who mentioned a positive and significant relationship between fish weight and standard length, fish weight and weight of gonad in Tilapia zilli $(\mathrm{P}<$ 0.05). Furthermore, similar result in Nile tilapia was obtained with (Mohamed et al., 2014) who reported that ovary weight was significantly $(\mathrm{P}<0.001)$ affected with the female size. As for egg weight, the obtained significant effect of female size on egg weight was previously reported on some fishes as larger females often produce larger eggs (Marteinsdottir and begg, 2002; Rideout et al., 2005). This phenomenon also reported in tilapia by Peters and Pauly (1983) who concluded that the weight of single eggs in tilapia varies widely and egg weight increases with body weight. As for fecundity, the present results revealed that total fecundity increased with increasing body size of females; which was in agreement with Hashem and El Agamy (1977) who stated that fecundity is a function related to length, weight and age of different fish species and increased with the increase in these parameters. Other studies concluded the same relationship between female size and absolute fecundity in tilapia (Watanabe and Kuo, 1985; Bhujel, 2007; Bombata and Megbowon, 2012; Mohamed et al., 2014). As for relative fecundity the results showed that the highest relative fecundity was recorded in the smallest females and was lower in medium and largest ones. The present results were in agreement with Farag, (2003) who found that the highest relative fecundity increased with the decrease in female body weight. On the other hand other studies reveled that, relative fecundity was significantly $(\mathrm{P}<0.001)$ affected with female size but increased at large-sized while decreased for medium and small-sized respectively (Mohamed et al., 2013; Mohamed et al., 2014).

\section{Fry production performance}

The results showed that the total collected fry number from each hapa was significantly $\mathrm{P}<0.001$ affected with the size brood-stock combinations. Furthermore, fry weight, length, and condition factor at 6 weeks old were all significantly $\mathrm{P}<0.001$ affected with the size broodstock combinations. On the other hand, survival rate wasn't significantly affected by broodstock size combinations (Table 4).

The data (Table 4) showed that $\mathrm{AB}, \mathrm{AC}$, and $\mathrm{BC}$ broodstock combinations were the highest concerning fry number collected from each hapa as 2960, 2430, and 2385 fry/hapa respectively while $\mathrm{CB}$ and $\mathrm{BA}$ combination showed the lowest fry number as 585 and $605 \mathrm{fry} / \mathrm{hapa}$. In tilapia agonistic interactions follows a hierarchical structure that forms a linear relationship based on size (Oliveira and Almada, 1996). Alpha males are the largest in the group and showed the greatest display of aggression. In addition, before reproduction in tilapia there are primary courtship displays and preparation such as digging the nest and defense displays (Oliveira and Almada, 1998). The present results suggest that using males which are larger than females in mating groups perhaps improve the courtship between males and females. The lowest fry number which obtained from combination $\mathrm{BA}$ and $\mathrm{CB}$ with a lower female size than male may also confirm the same explanation. Concerning fry body weight and length the results showed that the highest fry weight and length obtained from combinations AA, BB, and CA (1.71 g \& $4.45 \mathrm{~cm}) ;(1.49 \mathrm{~g} \mathrm{\&} 4.32 \mathrm{~cm})$; and $(1.35 \mathrm{~g} \mathrm{\&} 4.20 \mathrm{~cm})$ respectively while $\mathrm{BC}$ and $\mathrm{AC}$ combination showed the lowest fry weight $(1.27 \mathrm{~g}, 4.08 \mathrm{~cm})$ and $(1.2 \mathrm{~g} \mathrm{\&} 4.04$ $\mathrm{cm})$ respectively. Rana (1986) reported that Nile tilapia females of larger size were found to produce more and bigger eggs which were in agreement with the present results. Furthermore, El-Sayed and Gaber (2005) found that large eggs contained more yolk and led to larger fry with better growth. The previous results gave an explanation to the present results which indicate a superior weight and length of fry which resulting from combinations $\mathrm{AA}, \mathrm{BB}$, and $\mathrm{CA}$ and lowest weight and length of those which resulting from $\mathrm{BC}$ and $\mathrm{AC}$ combinations. 
Table (4): Fry production performance of $O$. niloticus as affected with different the size brood-stock combinations in the order of $(\hat{\sigma} \mathrm{X}+$ ).

\begin{tabular}{|c|c|c|c|c|c|}
\hline & $\begin{array}{l}\text { Fry } \\
\text { no. }\end{array}$ & $\begin{array}{c}\text { Fry weight } \\
\text { (g) }\end{array}$ & $\begin{array}{l}\text { Fry length } \\
\text { (cm) }\end{array}$ & $\begin{array}{l}\text { Fry } \\
\text { C.F. }\end{array}$ & Survival rate $\%$ \\
\hline $\mathbf{A A}$ & $\begin{array}{l}1810^{c} \\
\pm 73.9\end{array}$ & $\begin{array}{l}1.71^{\mathrm{a}} \\
\pm 0.05\end{array}$ & $\begin{array}{c}4.45^{\mathrm{a}} \\
\pm 0.055\end{array}$ & $\begin{array}{c}1.80^{\mathrm{c}} \\
\pm 0.042\end{array}$ & 93.4 \\
\hline $\mathbf{B A}$ & $\begin{array}{c}605^{\mathrm{e}} \\
\pm 73.9\end{array}$ & $\begin{array}{l}1.25^{\mathrm{d}} \\
\pm 0.05\end{array}$ & $\begin{array}{c}4.07^{\mathrm{d}} \\
\pm 0.055\end{array}$ & $\begin{array}{c}1.83^{\mathrm{c}} \\
\pm 0.042\end{array}$ & 91.5 \\
\hline $\mathbf{C A}$ & $\begin{array}{l}1560^{\mathrm{d}} \\
\pm 73.9\end{array}$ & $\begin{array}{l}1.35^{\mathrm{c}} \\
\pm 0.05\end{array}$ & $\begin{array}{c}4.20^{\mathrm{c}} \\
\pm 0.055\end{array}$ & $\begin{array}{c}1.82^{\mathrm{c}} \\
\pm 0.042\end{array}$ & 91.6 \\
\hline $\mathbf{A B}$ & $\begin{array}{l}2960^{\mathrm{a}} \\
\pm 73.9\end{array}$ & $\begin{array}{l}1.32^{\mathrm{d}} \\
\pm 0.05\end{array}$ & $\begin{array}{l}4.05^{\mathrm{d}} \\
\pm 0.055\end{array}$ & $\begin{array}{c}1.99^{\mathrm{a}} \\
\pm 0.042\end{array}$ & 90.0 \\
\hline BB & $\begin{array}{l}1755^{\mathrm{c}} \\
\pm 73.9\end{array}$ & $\begin{array}{l}1.49^{\mathrm{b}} \\
\pm 0.05\end{array}$ & $\begin{array}{c}4.32^{\mathrm{b}} \\
\pm 0.055\end{array}$ & $\begin{array}{c}1.88^{\mathrm{b}} \\
\pm 0.042\end{array}$ & 92.0 \\
\hline CB & $\begin{array}{c}585^{\mathrm{e}} \\
\pm 73.9\end{array}$ & $\begin{array}{l}1.31^{\mathrm{d}} \\
\pm 0.05\end{array}$ & $\begin{array}{c}4.14^{\mathrm{d}} \\
\pm 0.055\end{array}$ & $\begin{array}{c}1.83^{\mathrm{c}} \\
\pm 0.042\end{array}$ & 93.1 \\
\hline $\mathrm{AC}$ & $\begin{array}{l}2430^{\mathrm{b}} \\
\pm 73.9\end{array}$ & $\begin{array}{l}1.20^{\mathrm{e}} \\
\pm 0.05\end{array}$ & $\begin{array}{c}4.04^{\mathrm{d}} \\
\pm 0.055\end{array}$ & $\begin{array}{c}1.72^{\mathrm{d}} \\
\pm 0.042\end{array}$ & 93.5 \\
\hline BC & $\begin{array}{l}2385^{\mathrm{b}} \\
\pm 73.9\end{array}$ & $\begin{array}{l}1.27^{\mathrm{d}} \\
\pm 0.05\end{array}$ & $\begin{array}{c}4.08^{\mathrm{d}} \\
\pm 0.055\end{array}$ & $\begin{array}{c}1.82^{\mathrm{c}} \\
\pm 0.042\end{array}$ & 93.2 \\
\hline $\mathrm{CC}$ & $\begin{array}{l}1430^{\mathrm{d}} \\
\pm 73.9\end{array}$ & $\begin{array}{l}1.29^{\mathrm{d}} \\
\pm 0.05\end{array}$ & $\begin{array}{c}4.04^{\mathrm{d}} \\
\pm 0.055\end{array}$ & $\begin{array}{c}1.84^{\mathrm{c}} \\
\pm 0.042\end{array}$ & 95.1 \\
\hline Significance & $* * *$ & $* * *$ & $* * *$ & $* * *$ & $\mathrm{~ns}$ \\
\hline
\end{tabular}

\section{REFERENCES}

Bhujel, R. C. (2000). A review of strategies for the management of Nile tilapia (Oreochromis niloticus) brood fish in seed production systems, especially hapa-based systems. Aquaculture, 181: $37-59$.

Bhujel, R.C., D.C. Little and A. Hossain (2007). Reproductive performance and the growth of pre-stunted and normal Nile tilapia (Oreochromis niloticus) brood fish at varying feeding rates. Aquaculture, 273: 71-79.

Bombata, F. H. and I. Megbowon (2012). Proximate composition and breeding description of an unidentified Cichlid of Epe Lagoon, Lagos, Southwest, Nigeria commonly called 'Wesafu'. International Journal of Nutrition and Metabolism, 4: 57-63.

Bonferroni, C. E. (1936). Teoria statistica delle classi e calcolo delle probabilità." Pubblicazioni del R Istituto Superiore di Scienze Economiche e Commerciali di Firenze, 8: 3-62.

Borgeson, T. L., V. Racz, D.C. Wilkie, L. J. White and M. D. Drew (2006). Effect of replacing fishmeal and oil with simple or complex mixtures of vegetable ingredients in diets fed to Nile Tilapia (Oreochromis niloticus). Aquaculture Nutrition, 12: 141-149.

de Vlaming, V., GD. Grossman and F. Chapman (1982). On the use of the gonosomatic index. Comp Biochem Physiol, 73: 31-39.

El-Saidy, D. M. S. and M. M. A. Gaber (2005). Effect of dietary protein levels and feeding rates on growth performance, production traits and body composition of Nile Tilapia, (Oreochromis niloticus) (L.) cultured in concrete tanks. Aquac. Res., 36(2): 163-171.

El-Sayed, A. Y. (1996). Biological and Ecological studies on purse-seine fisheries in the Gulf of Suez. Ph.D. Thesis, Zool. Dep., Fac. Sci., Suez Canal Univ., Ismailia, Egypt.

FAO (2011). FAO Factsheet -Global Importance of a Growing Sector: Fisheries and Aquaculture. FAO, Rome, 128 pp.

FAO (2014). FAO Globefish Reports - Tilapia December 2014 Organization of the United Nations, Rome, Italy

Farag, M. S. (2003). Reproductive performance of Oreochromis niloticus through three seasons on earthen ponds. Egypt. J. Aquat. Biol. \& fish., 7(4): $263-282$.

Fath El-Bab, A. F., M. E. Farag, A. A. Ramadan and A. S. Hassan (2011). Effect of temperature and female weight on reproductive performance of two Nile tilapia (Oreochromis niloticus) populations Egypt. J. Aquat. Biol. \& Fish., 15 (2): 179-193.

Fitzsimmons, K. (2010). Potential to Increase Global Tilapia Production. Global Outlook for Aquaculture Leadership. Kuala Lumpur. The Global Aquac. Alliance., 13: 21-28.

Gómez-Márquez, J. L., B. Peña-Mendoza, I. H. Salgado-Ugarte and M. Guzmán-Arroyo (2003). Reproductive aspects of Oreochromis niloticus (Perciformes: Cichlidae) at Coatetelco lake, Morelos, Mexico. Rev. Biol.Trop., 51: 221-228.

Hashem, M. T. and A. El-Agamy (1977). Effect of fishing and maturation on the barbusbynni population of the NozhaHydrome. Bull Inst. Ocean and fish A. R. E., 7: 137-151. 
Hunter, J. R., B. J. Macewicz, N. C. Lo and C. A. Kimbrell (1992). Fecundity, spawning and maturity of female Dover sole Microstomus pacificus, with an evaluation of assumptions and precision. Fish. Bull. US., 90: 101-128.

Kirpichnikov, V. S. (1981). Genetic Bases of Fish Selection. Springer-Verlag, New York, New York.

Le Cren, E. D. (1951). The lenght-weight relationship and seasonal cycle in gonad weight and conditions in the perch Perca fluviatilis. Journal of Animal Ecology, London, 20 (2): 201-219.

Macaranas, J. M., P. B. Mather, S. N. Lal, T. Vereivalu, M. Lagibalavu and M. F. Capra (1997). Genotype and environment: a comparative evaluation of four tilapia stocks in Fiji. Aquaculture, 150: 11-24.

Marteinsdottir, G. and G. A. Begg (2002). Essential relationships incorporating the influence of age, size and condition on variables required for estimation of reproductive potential in Atlantic cod Gadus morhua. Mar. Ecol., Prog. Ser., 235: 235-256.

Mohamed, A. H., R. Ferdinand, M. Traifalgar and E. S. Augusto (2013). Maternal size affects fecundity of saline-tolerant tilapia (Peters) in freshwater tanks. Scholars Research Library Annals of Biol. Res., 4 (3): 138-142.

Mohamed, W. M., S. M. A. Shehata, G. O. El-Naggar, A. M. M. Khater and M. K. Mahmoud (2014). Effect of female weight on reproductive performance of Nile Tilapia (Oreochromis niloticus) $4^{\text {th }}$ Conference of Central Laboratory for Aquaculture Research, 315-332.

Oliveira, R. F. and V. C. Almada (1996). "Dominance hierarchies and social structure in captive groups of the Mozambique tilapia Oreochromis mossambicus (Teleostei Cichlidae)". Ethology Ecology \& Evolution 8: 39-55.

Oliveira, R. F. and V. C. Almada (1998). Mating tactics and male-male courtship in the lek breeding cichlid Oreochromis mossambicus. Journal of Fish Biology, 52: 1115-1129.

Oso J. A., O. A. Ogunleye, E. O. Idowu and F. A. Majolagbe (2013). Gonado-Somatic Index, Sex Ratio and Fecundity of Tilapia zilli in a Tropical Reservoir, South West Nigeria. Journal of Biology, 1(2): 42-45.

Peters, H. M. and D. Pauly (1983). Fecundity, egg weight, and oocyte development in tilapias (Cichlidae, Teleostei). International Center for Living Aquatic Resources Management, 28 pp.

Rana, K. J. (1986). Parental influences on egg quality, fry production and fry performance in Oreochromis niloticus Linnaeus and $O$. mossambicus Peters. PhD Thesis, Institute of Aquaculture, University of Stirling, UK, $295 \mathrm{pp}$.

Rideout, R. M., E. A. Trippel and M. K. Litvak (2005). Effects of egg size, food supply and spawning time on early life history of haddock Melanogrammus aeglefinus. Mar. Ecol., Prog. Ser., 285: 169-180.

Shalloof, K. A. S. and H. M. M. Salama (2008). Investigations on some aspects of reproductive biology in Oreochromis niloticus (Linnaeus, 1757) inhabited Abu-Zabal Lake, Egypt. Global Vet., 2: 351-359.

Watanable, W. O. and C. M. Kuo (1985). Observation on the reproductive performance of Nile tilapia Oreochromis niloticus in the laboratory aquaria at variance salinities. Aquacult., 49: 323.

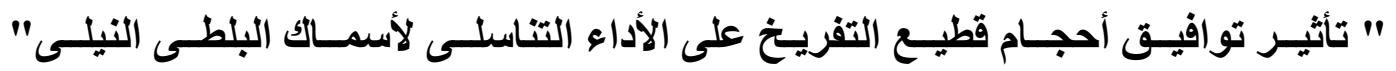

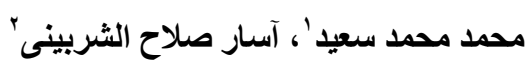

